\title{
A GYERMEK- ÉS SERDÜLÖKORI KÖVÉRSÉG MEGHATÁROZÁSÁNAK TESTZSÍROSSÁG MUTATÓIRA ÉPÜLŐ, ÚJ HAZAI HATÁRÉRTÉKEI
}

\author{
Zsákai Annamária, Fehér Virág Piroska, Annár Dorina és Bodzsár Éva \\ Embertani Tanszék, Eötvös Loránd Tudományegyetem, Budapest
}

\begin{abstract}
Zsákai A., Fehér V. P., Annár D., Bodzsár É.: New Hungarian cut-off values of childhood obesity based on body fatness indicators. The increasing prevalence of obese children and adolescents emphasizes the importance of national and international standards for screening childhood obesity. The main aim of the study was to construct the Hungarian cut-off values of waist-to-hip ratio, body fat percentage and visceral fat area to diagnose obesity and abdominal obesity in children aged between 7 and 18 years. The distribution of obese children diagnosed by the international standards as well as by the new national standards was compared in the analysis. A group of healthy children (n: 869 boys and 881 girls, aged between 7 and 18 years) formed the sample of the present analysis. Body composition and body fat distribution of subjects was estimated body impedance analysis (Inbody 720 device, Biospace, USA) and by anthropometric methods. Nutritional status was estimated by body mass index. The international cut-off values of body fatness indicators determined for adults as well as the centile distribution of body fatness indicators by age were used to construct the critical cut-off values of obesity and abdominal obesity in the studied age-group of subadults.

By considering the results of the present analysis the age-dependent 95th centiles of body fat percentage and visceral fat area were recommended for screening childhood obesity and abdominal obesity in the studied age-group in both genders.
\end{abstract}

Keywords: Body fatness; Obesity; Waist-to-hip ratio; Visceral fat area; Screening; Children, adolescents.

\section{Bevezetés}

Az emberi test zsírtartalma az ún. esszenciális zsír és a tartalékzsír formájában raktározódik. Legjelentősebb esszenciális zsírraktáraink a csontvelőben, izomszövetben, zsigereinkben és a központi idegrendszer lipid-gazdag régióiban találhatók meg, illetve a sejtek hártyájának fontos összetevői a zsírmolekulák. Az esszenciális zsír mennyisége jelentős nemi különbséget mutat (reprodukciós szerepek különbségei miatt), felnőtt férfiakban a testtömeg 3-5\%-át teszi ki, ezzel szemben a felnőtt nőkben mennyisége eléri a 10-12\%-ot is. Az esszenciális zsír mennyisége jelentősen nem csökkenhet ezen értékek alá anélkül, hogy fontos élettani funkcióink ne sérülnének (például megfelelő mennyiségü esszenciális zsír szükséges a megfelelő hőszabályozáshoz és energiatermeléshez; Lohman és Going 2006, Wells 2007).

Testünk legnagyobb tartalékzsír raktárai a bőralatti rétegben, illetve a zsigerek között találhatóak. A tartalékzsír mennyisége is nemi és életkori különbséget mutat, mindezen túl életmódunk tényezői, köztük is leginkább táplálkozásunk és fizikai aktivitásunk tényezői, illetve általános egészségi állapotunk is jelentős mértékben befolyásolja a tartalékzsír mennyiségét (Shen és mtsai 2009, Bodzsár és Zsákai 2012). 
A tartalékzsír megnövekedett mennyisége kezdetben túlsúlyhoz, majd mennyiségének további fokozódása elhízáshoz vezet, míg csökkent mennyisége esetében rosszul táplált állapot alakulhat ki. Mindezek hátterében a felvett és felhasznált energia arányának eltolódása áll. A tápláltsági állapot ezen zavarait természetesen a test további összetevőinek rendellenes mennyiségei is kísérik, így a rosszul tápláltak, túlsúlyosak, ill. elhízottak izom- és csontkomponenseinek mennyisége is általában jelentősen eltér a normál tápláltsági állapotú, azonos nemü kortársaikétól. Éppen ezért a megnövekedett, ill. csökkent zsírtömeg jellemzésére ajánlatos az abszolút és relatív mennyiség mutatóit együttesen használni (Jensen 2008, Garg 2011).

Az Egészségügyi Világszervezet (WHO 2011) ajánlásai alapján kiemelt jelentőségü, hogy a tápláltsági állapot, testösszetétel jellemzésékor a zsírtömeg mutatóin túl a zsíreloszlás mutatóit is figyelembe vegyük, hiszen a tápláltsági állapot zavarait kísérö betegségek kockázata a testmagassághoz viszonyított testtömeg, az abszolút és relatív zsírtömeg mutatóinak ismeretén túl a zsíreloszlás ismeretében pontosabban becsülhető (Björntorp 1991, Smith és mtsai 2001).

A zsírtömeg mennyisége becsülhető a böralatti zsírréteg vizsgálatára épülő antropometriai módszerrel (bőrredővastagságok alapján történő szubkután zsírtömeg becslése), bőrellenállás mérésén alapuló testösszetétel-analízissel (bioelectrical impedance analysis, BIA), nagy müszeres képalkotó technikák (MR, CT, DEXA) segítségével. Míg a zsírraktárak eloszlása vizsgálható a derékkerület-csípőkerület hányadosával (waist-to-hip ratio, WHR), a BIA módszer által becsült abdominális zsírtömeggel, illetve a képalkotó módszerek által regionálisan becsült abszolút és relatív zsírtömeg segítségével (Deurenberg és Yap 1999).

A népegészségügyi szürővizsgálatok során a kövér tápláltsági állapot jellemzésére leggyakrabban használt testszerkezeti mutató a testtömeg-index, míg az abdominális kövérség meghatározása leggyakrabban a derékkerület-csípőkerület hányadosa alapján történik (Hsieh és Yoshinaga 1995, WHO 2000, 2011, Reilly 2005, Okorodudu és mtsai 2010). A WHO a kövérség BMI-n alapuló határértékét felnőttek esetében nemtöl és rasszbeli hovatartozástól függetlenül határozta meg (WHO 2000), a $30 \mathrm{~kg} / \mathrm{m}^{2}$-től nagyobb testtömeg-index a kövér tápláltsági állapotot jelenti felnőttek esetében. Az elmúlt évtizedben felmerült a határérték rasszbeli hovatartozástól függő módosítása, mongolid népességeknél a vizsgálatok alapján egyre több epidemiológus az index $28 \mathrm{~kg} / \mathrm{m}^{2}$ értékét ajánlja a kövérség határértékének (Zhou 2002, Ma és mtsai 2005, Weng és mtsai 2006) az ember földrajzi változatainak testszerkezeti különbségei miatt. A gyermekek és serdülök esetében a BMI életkortól és nemtől függő, nemzetközi határértékei használatosak a kövér tápláltsági állapot meghatározására (Cole és mtsai 2000). A WHR abdominális kövérséget meghatározó, WHO által megadott felnőttkori határértéke férfiak esetében 0,90 , míg nők esetében 0,85 . Gyermekek és serdülökorúak abdominális kövérségét kijelölő, általánosan elfogadott WHR határértékek még nem léteznek (Taylor és mtsai 2000, Fredriks és mtsai 2005, Fujita és mtsai 2011, Magalhaes és mtsai 2014).

Mindezek a testszerkezeti mutatók mellett a testzsírszázalékot használják leggyakrabban a kövérség diagnózisának felállításakor. A nemzetközi ajánlások ebben az esetben sem egybehangzóak, Jeukendrup és Gleeson (2010) a férfiak esetében a 24\%-nál, míg a nők esetében a 37\%-nál nagyobb zsírszázalékot ajánlják a kövérség meghatározására (testzsírszázalék-becslő módszertől függetlenül). Nemzetközileg a kövérség megállapításának leggyakrabban használt határértékei azonban a >25\%-os (férfiak) és > 35\%-os (nők) értékek (WHO 1995, Lohman és mtsai 1997, Deurenberg és 
mtsai 2001, Okorodudu és mtsai 2010 - bőrredők alapján becsült testzsírszázalék esetén; Bosy-Westphal és mtsai 2006 - DEXA vizsgálatok alapján becsült testzsírszázalék esetén; Phillips és mtsai 2013 - BIA TANITA típusú müszerrel becsült testzsírszázalék esetén). A testzsírszázalék becslésekor a különböző módszerekkel becsült értékek között jelentős különbségek figyelhetők meg (akár 2-4\% is lehet a különbség, Shah és Braverman 2012), ezért kiemelt jelentőségü, hogy a testzsírszázalék alapján történő tápláltsági állapot besoroláskor (kövér, ill. nem kövér alcsoportokba) a becslés során alkalmazott módszerre meghatározott életkori határértékeket használjuk.

A BIA módszerrel becsült viszcerális zsírterület esetében a $100 \mathrm{~cm}^{2}$-től nagyobb zsírterületet ajánlják az abdominális kövérség határértékeként felnőtteknél (Kim és mtsai 1998, Examination Committee of Criteria for 'Obesit Disease' in Japan, Japan Society for Study of Obesity 2002, Berker és mtsai 2010). Gyermekek és ifjak esetében a viszcerális zsírterület kövérséget jelző kritikus határértékét még nem határozták meg (El-Masry és mtsai 2011).

Mindezek alapján elemzésünk célja volt, hogy a WHR, illetve az InBody 720-as típusú BIA testösszetétel-analizátorral becsült zsírszázalék és viszcerális zsírterület gyermek- és serdülőkori kövérség becslésére alkalmas hazai határértékeit meghatározzuk a vizsgálatban részvett egészséges gyermekek és serdülők testszerkezeti adatai alapján. Célunk volt továbbá, hogy a testzsírosság ezen mutatói alapján a nemzetközileg már korábban elfogadott és most meghatározásra kerülő hazai határértékek szerint a vizsgált 7-18 évesek mintájában kövérnek, illetve abdominálisan kövérnek minősülő gyermekek alcsoportjainak eloszlásmintázatának elemezése.

\section{Vizsgált személyek és alkalmazott módszerek}

Az elemzés alapjául szolgáló mintában részvevő összesen 1750 gyermek és serdülő (7-18 évesek, 869 fiú és 881 leány, 1. táblázat) testszerkezeti vizsgálatát 2014-2015-ben végeztük el. A gyermekek testzsírosságának mutatóit (testzsírtömeg, abdominális zsírfrakció) börellenállás-mérésen alapuló testösszetétel-analizátorral becsültük (InBody 720 típusú müszer, Biospace, Los Angeles, USA). A testméretek vizsgálatát az antropometriai vizsgálatokban használatos standard eszközök és standard módszerek segítségével végeztük el (Weiner és Lourie 1969). A gyermekek tápláltsági állapotát a testtömeg-index életkori határértékei alapján határoztuk meg (Cole és mtsai 2000).

1. táblázat. A vizsgált gyermekek életkori és nemi megoszlása.

Table 1. The distribution of subjects by age and gender.

\begin{tabular}{lccccccccccccc}
\hline & \multicolumn{1}{c}{} & \multicolumn{11}{c}{ Életkor (év) - Age (years) } & \multicolumn{1}{c}{ Együtt - } \\
& 7 & 8 & 9 & 10 & 11 & 12 & 13 & 14 & 15 & 16 & 17 & 18 & Together \\
\hline Fiúk-Boys & 51 & 118 & 92 & 95 & 90 & 52 & 78 & 51 & 71 & 76 & 48 & 47 & 869 \\
Leányok-Girls & 45 & 98 & 78 & 77 & 89 & 71 & 89 & 69 & 70 & 81 & 60 & 54 & 881 \\
\hline
\end{tabular}

Az elemzéshez szükséges statisztikai elemzéseket az SPSS v. 20 programcsomaggal végeztük. Hipotéziseinket 5\%-os szinten teszteltük. A testzsírosság mutatóinak centilismintázatait az lmsChartMaker Pro 2.3 (Medical Research Council, UK 19972006) szoftverrel szerkesztettük meg. A nemzetközi ajánlások alapján a fiúk esetében a 0,90-es WHR értéken, a 25\%-os testzsírszázalékon és a $100 \mathrm{~cm}^{2}$-es VFA értéken, míg a leányoknál a 0,85-ös WHR értéken, a 35\%-os testszírszázalékon és szintén a $100 \mathrm{~cm}^{2}$-es 
VFA értéken 18 éves korban áthaladó centiliseket határoztuk meg a kövérség kritikus határértékeinek elemzésekor (Zsákai és mtsai 2007).

\section{Vizsgálati eredmények és értékelésük}

A vizsgált testzsírossági mutatók centilismintázatát elemezve megállapítható, hogy a fiúk testzsírszázaléka átlagosan 10 éves korig fokozódik, majd 10 éves kor után a testzsír relatív mennyisége csökken a fiúk testében 16 éves korig, és újból növekedésnek indul a vizsgált korintervallum végén (1. ábra). Ezzel szemben a leányok átlagos testzsírszázaléka monoton növekedést mutatott végig a vizsgált életkori intervallumban. A WHR index értéke mindkét nem esetében csökken az életkor elörehaladtával 7 éves kortól, azonban a fiúk csoportjában a csökkenés átlagosan 14 éves korig jellemző, majd a WHR-nek a vizsgált korintervallum végén újbóli növekedése figyelhető meg. A leányoknál ezzel szemben a WHR monoton csökkenése jellemzi a vizsgált korintervallumot, 15 éves kortól a leányoknál az index értékének csökkenése lelassul (2. ábra). A viszcerális zsírterület monoton növekedése figyelhető meg mindkét nem esetében 7 és 18 éves kor között, leányoknál a VFA értékének növekedése átlagosan 14 éves kortól lelassul (3. ábra).
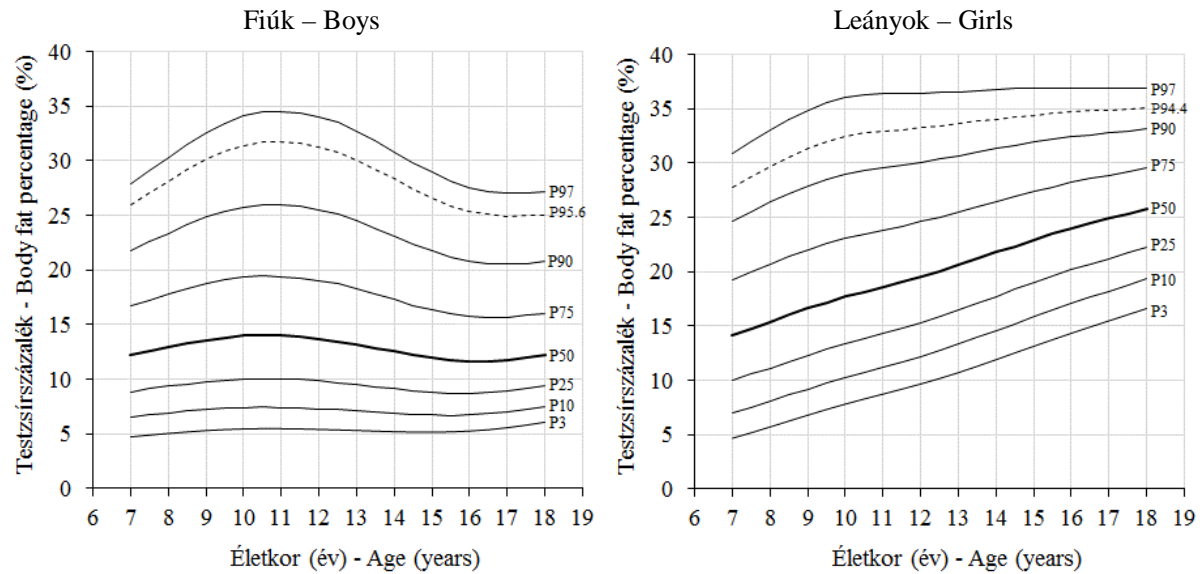

1. ábra: Testzsírszázalék (\%) centilismintázata 7-18 éves gyermekekben (- - -: a kövérség felnőttkori határértékein 18 éves korban áthaladó testzsírszázalék centilisek).

Fig. 1: Centile distribution of body fat percentage (\%) in children aged between 7 and 18 (- - -: body fat percentage centiles crossing the critical cut-off values of obesity of adults at the age of 18).

A centilismintázatok alapján kijelenthetjük, hogy a fiúk esetében a VFA $100 \mathrm{~cm}^{2}$-es és a testzsírszázalék esetében a 25\%-os felnőttkori határérték figyelembe vételével meghatározott kritikus centilis-görbe alapján a vizsgált mintában szereplö fiúk nagyjából 5\%-a sorolható be a kövérek alcsoportjába (VFA: 94,2. centilise, testzsírszázalék 95,6. centilise). A VFA és testzsírszázalék $100 \mathrm{~cm}^{2}$-es, ill. 35\%-os felnőttkori női határértéke alapján kijelölt centilisek a leányok kevesebb, mint 2\%-át, illetve közel 5\%-át határozta meg kövérnek (VFA 98,8. centilise, testzsírszázalék 94,4. centilise, 1. és 3. ábra). A WHR nemzetközi kritikus határértékein (férfiak: 0,90, nők: 0,85) áthaladó centilisek (fiúk: 80,5. centilis, leányok: 91,6. centilis) alapján a fiúk 19,5\%-a, a leányok 8,4\%-a minősíthető abdominálisan kövérnek (2. ábra). 

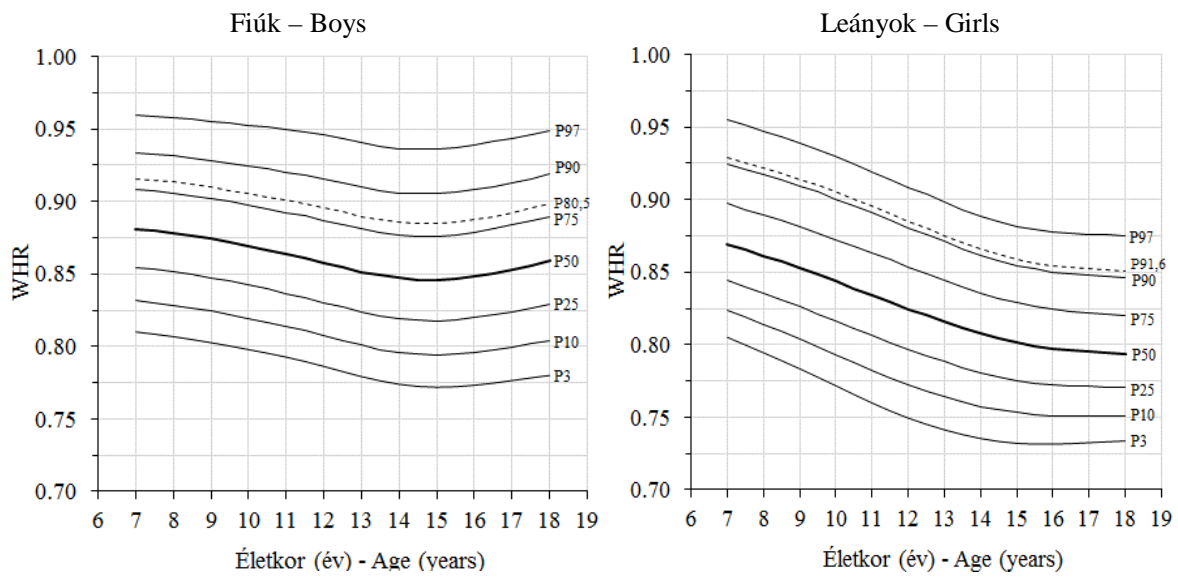

2. ábra: WHR centilismintázata 7-18 éves gyermekekben (- - -: a kövérség felnőttkori határértékein 18 éves korban áthaladó WHR centilisek).

Fig. 2: Centile distribution of WHR in children aged between 7 and 18 years (- - -: WHR centiles crossing the critical cut-off values of obesity of adults at the age of 18).
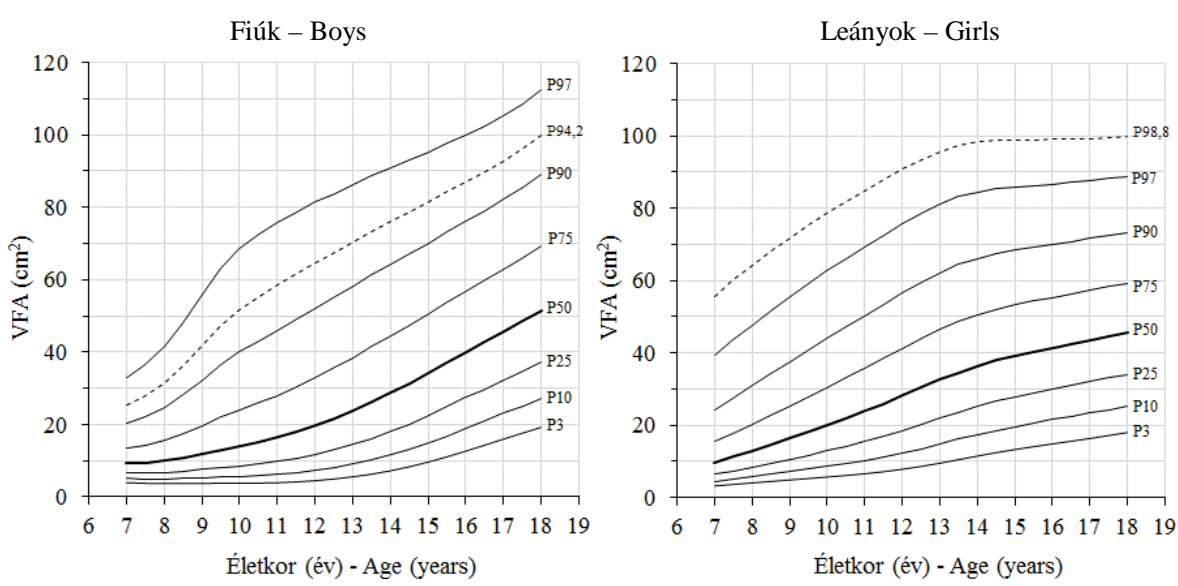

3. ábra: Zsigeri zsírterület (VFA, $\mathrm{cm}^{2}$ ) centilismintázata 7-18 éves gyermekekben (- - -: a kövérség felnőttkori határértékein 18 éves korban áthaladó VFA centilisek).

Fig. 3: Centile distribution of visceral fat area $\left(\mathrm{VFA}, \mathrm{cm}^{2}\right)$ in children aged between 7 and 18 years (- - -: VFA centiles crossing the critical cut-off values of obesity of adults at the age of 18).

A testtömeg-index alapján a fiúknak 2,5\%-a és a leányoknak 2,3\%-a kövér a vizsgált korintervallumban (4. ábra). Összességében a BMI alapján kövérnek minősített gyermekek aránya a két nem között nem különbözik jelentősen ( $\chi^{2}$ próba, $p=0,803$ ), azonban a tendencia megfigyelhetö, hogy a leányoknál a 15 évestől idősebbek korcsoportjaiban már nem volt kövér tápláltsági állapotú.

A BMI és az új testzsírszázalék határértékek alapján elvégzett tápláltsági állapot-besorolás a gyermekek jelentős százalékában megegyezett (fiúk: 94,3\%, leányok: 95,9\%), a két besorolás között a legnagyobb eltérést a BMI alapján még nem kövér, de a testzsírszázalék alapján már kövérnek minősített gyermekek alcsoportja jelentette (5. ábra). 


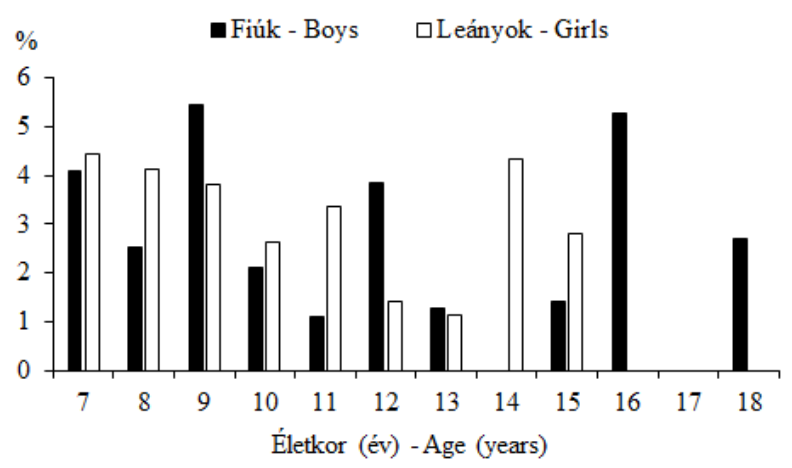

4. ábra: A testtömeg-indexük alapján elhízottnak minősített gyermekek relatív előfordulási gyakorisága. Fig. 4: The prevalence of children rated obese by considering their body mass index.
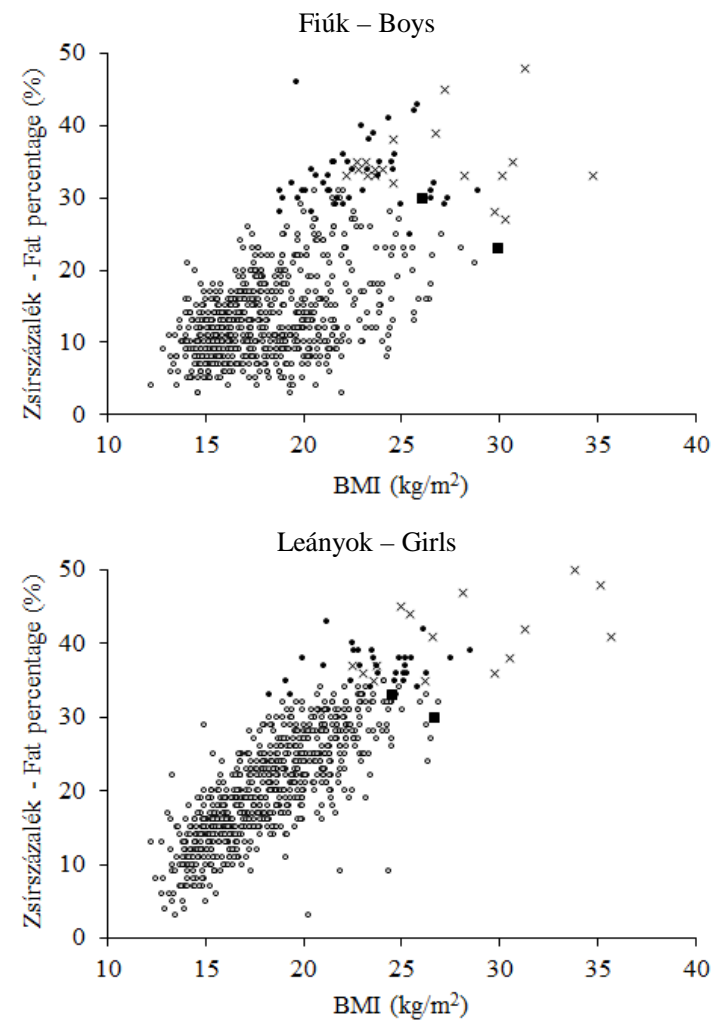

5. ábra. A zsírszázalék és a BMI kapcsolata gyermekekben (०: BMI és zsírszázalék határértékek alapján sem kövér gyermekek, •: kövér gyermekek a zsírszázalék határértékek, de nem kövér gyermekek a BMI határértékek alapján; : : kövér gyermekek a BMI határértékek, de nem kövér gyermekek a testzsírszázalék határértékek alapján; ×: a BMI és a zsírszázalék határértékek alapján is kövér gyermekek).

Fig. 5. The relation of body fat percentage and BMI in children ( $\circ$ : not obese children by BMI and body fat percentage cut-off values; $\bullet$ : obese children by body fat percentage but not by BMI cut-off values; $\mathbf{m}$ : obese children by BMI but not by body fat percentage cut-off values; $\times$ : obese children both by body fat percentage and BMI cut-off values). 
A WHR és VFA határértékek alapján kialakított abdominálisan kövér alcsoportok a BMI-testzsírszázalék besorolás nagymértékü egyezőségével szemben nagyon csekély egyezőséget mutatott (fiúk: 87,9\%, leányok: 87,5\%), és a két folyamatos változó, a WHR és a VFA eloszlásmintázata sem mutatott statisztikailag igazolható kapcsolatot (6. ábra).
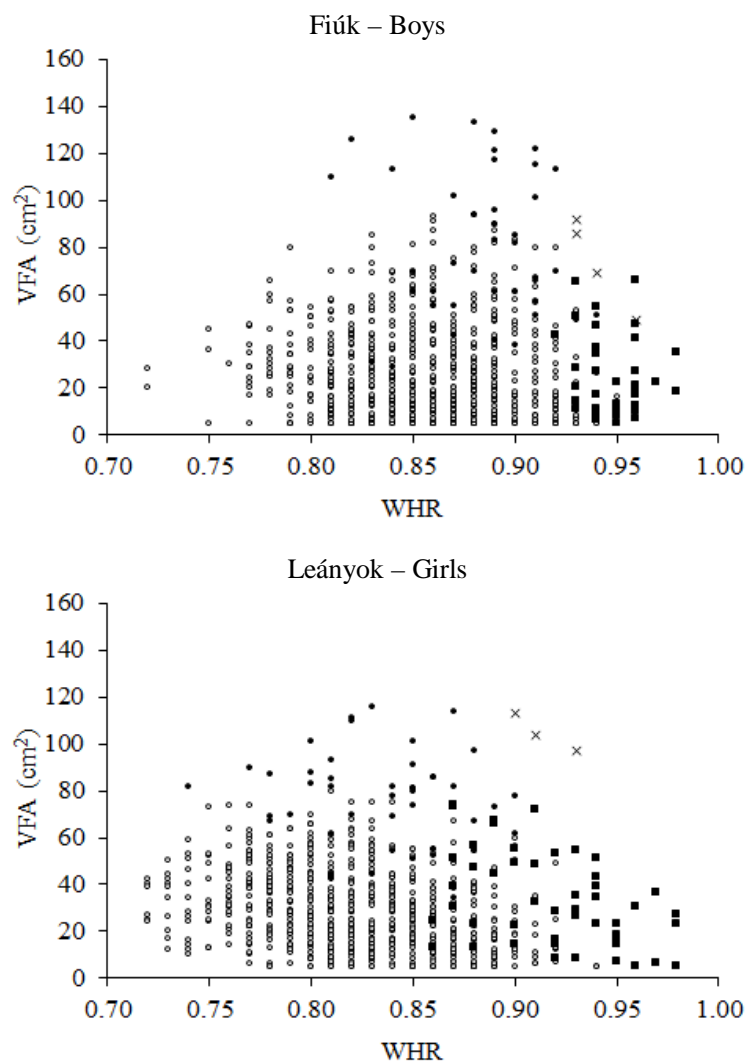

6. ábra. A VFA és WHR kapcsolata gyermekekben ( ${ }^{\circ}$ VFA és WHR határértékek alapján sem

kövér gyermekek, •: kövér gyermekek a VFA határértékek, de nem kövér gyermekek a WHR határértékek alapján; : : kövér gyermekek a WHR határértékek, de nem kövér gyermekek a VFA határértékek alapján; ×: a VFA és a WHR határértékek alapján is kövér gyermekek).

Fig. 6. The relation of VFA and WHR in children ( ${ }^{\circ}$ : not obese children by VFA and WHR cut-off values; $\bullet$ : obese children by VFA but not by WHR cut-off values; $\mathbf{m}$ : obese children by WHR but not by VFA cut-off values; $\times$ : obese children both by VFA and WHR cut-off values).

\section{Következtetések}

A 7-18 évesek testszerkezeti adatai alapján elvégzett elemzés alapján a testzsírosság mutatóinak életkori határértékeire vonatkozóan a következő megállapításokat tehetjük:

1) A nemzetközi ajánlásokkal szemben, vizsgálati eredményeink alapján nem a nemtől független, fiúk és leányok esetében azonos felnőttkori határérték által kijelölt centilisek értékeinek használatát javasoljuk a gyermek- és serdülőkori kövérség testzsírossági mutatókra épülő határértékeinek kijelölésére. Ehelyett inkább a gyermekek és serdülők azonos arányát kijelölő 95. centilisek értékeit ajánljuk a kövérség ilyen típusú szüréséhez, ami tehát azonos arányban jelöli ki a 
kövér gyermekeket a két nemben (5\%-ot), azonban a kövérség mutatóinak nemi dimorfizmusa miatt így a kritikus határértékek is értelemszerüen eltérőek a két nem esetében. Javaslatunkat alapvetően arra hivatkozva tesszük meg, hogy azonos arányú testzsírosság nem feltétlenül jelez ugyanolyan tápláltsági állapotot a két nem esetében, hiszen a testösszetevők közül nemcsak a zsír, hanem a csont- és izomtömeg frakciók is jelentős nemi különbséget mutatnak.

2) A WHR felnőtteknél javasolt, nemzetközi határértékei alapján megszerkesztett kritikus centilisei a gyermekek irreálisan nagy arányát határozták meg abdominálisan kövérnek. A WHR és a VFA mutatók alapján kövérnek minősülő gyermekek besorolása nagyon gyenge kapcsolatot mutatott. Mindezek alapján a WHR-t nem javasoljuk a 7-18 éveseknél az abdominális kövérség szürésére.

3) Elemzésünk eredményeire alapozva a két másik vizsgált testzsírossági mutatónak, az InBody 720 típusú testösszetétel-analizátorral becsült testzsírszázaléknak és a VFA indexnek az általunk elemzett mintára jellemző 95. centiliseit ajánljuk (2. táblázat) a kövérség határértékeinek gyermekek és serdülök esetében, hiszen csak a leányok abdominális zsírterületének felnőttkori kritikus határértéket 18 éves korban érintő centilise nem haladt a 95. centilis közelében, amely 98,8. VFA centilis értékeinek használata bizonyosan alulbecsülné az abdominálisan kövér leányok gyakoriságát (1,2\%).

2. táblázat. A gyermek- és serdülőkori kövérség meghatározására ajánlott testzsírossági mutatók új hazai határérékei (95. centilisek).

Table 2. The new Hungarian critical cut-off values of body fatness indices to assess obesity in children and adolescents (95th centiles).

\begin{tabular}{|c|c|c|c|c|c|c|}
\hline \multirow{3}{*}{$\begin{array}{l}\text { Életkor (év) } \\
\text { Age (ys) }\end{array}$} & \multicolumn{2}{|c|}{$\begin{array}{c}\text { VFA } \\
\left(\mathrm{cm}^{2}, \text { InBody } 720\right)\end{array}$} & \multicolumn{2}{|c|}{$\begin{array}{c}\text { Testzsírszázalék - Relative } \\
\text { fat mass (\%, InBody 720) }\end{array}$} & \multicolumn{2}{|c|}{$\begin{array}{l}\text { Testzsírszázalék - Relative } \\
\text { fat mass (\%, Siri 1956) }\end{array}$} \\
\hline & Fiúk & Leányok & Fiúk & Leányok & Fiúk & Leányok \\
\hline & Boys & Girls & Boys & Girls & Boys & Girls \\
\hline 7,0 & 28,39 & 32,17 & 25,33 & 28,36 & 27,17 & 30,93 \\
\hline 7,5 & 30,11 & 36,27 & 26,38 & 29,36 & 28,02 & 31,92 \\
\hline 8,0 & 33,33 & 40,20 & 27,41 & 30,32 & 28,90 & 32,91 \\
\hline 8,5 & 38,38 & 43,99 & 28,40 & 31,21 & 29,78 & 33,83 \\
\hline 9,0 & 44,92 & 47,66 & 29,30 & 31,99 & 30,61 & 34,66 \\
\hline 9,5 & 50,87 & 51,25 & 30,04 & 32,63 & 31,26 & 35,34 \\
\hline 10,0 & 54,18 & 54,71 & 30,55 & 33,10 & 31,65 & 35,86 \\
\hline 10,5 & 55,87 & 58,05 & 30,83 & 33,40 & 31,81 & 36,21 \\
\hline 11,0 & 57,96 & 61,30 & 30,88 & 33,57 & 31,89 & 36,45 \\
\hline 11,5 & 61,16 & 64,48 & 30,73 & 33,70 & 31,80 & 36,62 \\
\hline 12,0 & 65,10 & 67,53 & 30,39 & 33,82 & 31,62 & 36,76 \\
\hline 12,5 & 69,06 & 70,32 & 29,87 & 33,97 & 31,42 & 36,84 \\
\hline 13,0 & 72,66 & 72,80 & 29,20 & 34,15 & 31,09 & 36,85 \\
\hline 13,5 & 75,85 & 74,92 & 28,40 & 34,37 & 30,64 & 36,78 \\
\hline 14,0 & 78,82 & 76,56 & 27,50 & 34,57 & 30,16 & 36,60 \\
\hline 14,5 & 82,12 & 77,73 & 26,61 & 34,74 & 29,57 & 36,62 \\
\hline 15,0 & 85,78 & 78,52 & 25,81 & 34,87 & 28,78 & 36,51 \\
\hline 15,5 & 89,23 & 79,09 & 25,16 & 34,99 & 27,84 & 36,29 \\
\hline 16,0 & 92,16 & 79,62 & 24,66 & 35,11 & 26,95 & 36,19 \\
\hline 16,5 & 94,82 & 80,22 & 24,36 & 35,20 & 26,35 & 36,05 \\
\hline 17,0 & 97,49 & 80,95 & 24,25 & 35,28 & 25,99 & 35,97 \\
\hline 17,5 & 100,29 & 81,75 & 24,28 & 35,33 & 25,68 & 35,88 \\
\hline 18,0 & 103,09 & 82,58 & 24,39 & 35,39 & 25,57 & 35,89 \\
\hline
\end{tabular}


4) A gyermek- és serdülökori kövérség meghatározására nemzetközileg leggyakrabban használt mutató a BMI. A BMI és a testzsírszázalék közötti kapcsolat elemzése is megerősítette, hogy a pusztán BMI alapján történő tápláltsági állapotbesorolás nem vehető figyelembe a testzsírosság felmérésében a túlsúlyos gyermekek alcsoportjában, különösen igaz ez a fiúk esetében, akiknél a túlsúlyos gyermekek alcsoportjában a testzsírszázalék a korcsoportra jellemző átlagos értéket, attól jelentősen kisebb és nagyobb értékeket is elérhet.

A vizsgálatunkkal célunk volt az InBody 720 típusú testösszetétel-analizátorral becsült testzsírossági mutatók gyermek- és serdülőkori kövérség megállapításához ajánlható határértékek meghatározása, hiszen az általunk és az országban számos más szomatometriai laboratóriumában használt testösszetétel-analizátor a testösszetevők becslésekor bizonyosan nem magyar gyermekek és serdülök mintájára kidolgozott standardokhoz viszonyít a testösszetevők mennyiségének értékelésekor, illetve ezen értékelés nem a kövér vagy nem kövér tápláltsági állapotot határozza meg, hanem csak ajánlást ad az általa becsült testösszetevők esetleges korrekciójára. Azonban nem minden testösszetétel-becsléssel foglalkozó hazai szakember, laboratórium rendelkezik InBody 720 típusú müszerrel. Az összehasonlító vizsgálatok igazolták, hogy a bőrellenállás mérésen alapuló (pl. InBody 720 müszerrel) és az antropometriai méretekre épülő testösszetétel-elemzésekkel, amely antropometriai módszerek szintén a leggyakrabban használt eljárások a testösszetevők becslésére, becsült zsírszázalék értékek jelentős egyedi különbséget is mutathatnak az általunk vizsgált korcsoportban (Deurenberg és Yap 1999, Shah és Braverman 2012). Éppen ezért, az antropometriai módszer alapján gyermekeknél és serdülőknél testösszetevőket becsülő szakemberek számára az ajánlott határértékek között a 2. táblázatban feltüntettük a testsűrüség (Durnin és Womersley 1974, Bodzsár és Zsákai 2013) alapján becsült egyedi testzsírszázalék (Siri 1956, Bodzsár és Zsákai 2004) értékek eloszlás-mintázata figyelembevételével, antropometriai módszerrel meghatározott testzsírszázalék 95. centilis-értékeit is. A vizsgált mintában a két különböző módszerrel becsült zsírszázalék szoros kapcsolatot mutatott (Pearson féle korreláció, fiúk: r=0,786, $\mathrm{p}<0,05$; leányok: $r=0,805, \mathrm{p}<0,05$ ), azonban a Siri-féle testzsírszázalék becslés átlagosan 2-3\%-al meghaladta a bőrellenállás-mérésen alapuló módszerrel becsült testzsírszázalékot mindkét nem esetében.

A bemutatott eredményekre épülő további kutatásunkkal célunk, hogy a vizsgált korcsoportba tartozó gyermekek és serdülők egy új, kisebb létszámú mintáján a testzsírossági mutatók új határértékei alapján elkülönített alcsoportoknál a lipidanyagcsere, ill. májfunkciók becslésére az egészségügyi ellátórendszerben leggyakrabban használt mutatókat (pl. éhomi vércukorszint, éhomi lipid profil, inzulinrezisztencia index) összehasonlítsuk, valamint ezen élettani és a testzsírossági mutatók közötti kapcsolatrendszert a vizsgált korcsoportban elemezzük.

\section{$* * *$ \\ A tanulmánnyal köszöntik Bodzsár Éva professzor asszonyt 70. születésnapja alkalmából tanítványai.}

Köszönetnyilvánítás: A tanulmány a Bolyai János Kutatási Ösztöndíj támogatásával (ZsA, 2014-2017) készült. 


\section{Irodalom}

Berker, D., Koparal, S., Isik, S., Pasaoglu, L., Aydin, Y., Erol, K., Güler, S. (2010): Compatibility of different methods for the measurement of visceral fat in different body mass index strata. Interventional Radiology, 16(2): 99-105. DOI: 10.4261/1305-3825.DIR.2749-09.1

Björntorp, P. (1991): Metabolic implications of body fat distribution. Diabetes Care, 14(12): 1132-1143. DOI: $10.2337 /$ diacare.14.12.1132

Bodzsár, É., Zsákai, A. (2004): Humánbiológia. Gyakorlati kézikönyv. Eötvös Kiadó, Budapest. p. 300.

Bodzsár, É., Zsákai, A. (2012): Magyar gyermekek és serdülők testfejlettségi állapota - Országos Növekedésvizsgálat 2003-2006. Plantin Kiadó, Budapest. p. 240.

Bodzsár, É., Zsákai, A. (2013) Antropológiai/Humánbiológiai gyakorlatok. Elektronikus tananyag (TÁMOP-4.1.2.A/1-11/1-2011-0073).

Bosy-Westphal, A., Geisler, C., Onur, Korth, S.O., Selberg, O., Schrezenmeir, J., Müller, M.J. (2006): Value of body fat mass vs anthropometric obesity indices in the assessment of metabolic risk factors. International Journal of Obesity, 30: 475-483. DOI: 10.1038/sj.ijo.0803144

Cole, T.J., Bellizzi, M.C., Flegal, K.M., Dietz, W.H. (2000): Establishing a standard definition for child overweight and obesity worldwide: international survey. British Medical Journal, 320(7244): 1240-1247. DOI: 10.1136/bmj.320.7244.1240

Deurenberg, P., Andreoli, A., Borg, P., Kukkonen-Harjula, K., de Lorenzo, A., van Marken Lichtenbelt, W., Testolin, G., Vigano, R., Vollaard, N. (2001): The validity of predicted body fat percentage from body mass index and from impedance in samples of five European populations. European Journal of Clinical Nutrition, 55: 973-979. DOI: 10.1038/sj.ejcn.1601254

Deurenberg, P., Yap, M. (1999): The assessment of obesity: methods for measuring body fat and global prevalence of obesity. Best Practice \& Research Clinical Endocrinology \& Metabolism, 13(1): 1-11. DOI: $10.1053 /$ beem.1999.0003

Durnin, J.V., Womersley, J. (1974): Body fat assessed from total body density and its estimation from skinfold thickness measurements. British Journal of Nutrition, 32: 77-97.

El-Masry, S.A., El-Dayem, S., Elghawaby, H., Amin, F.G., Ibrahim, I.A. (2011): Evaluation of intra-abdominal fat in obese adolescents using computerized tomography. Medical Research Journal, 10(2): 89-96. DOI: 10.1097/01.MJX.0000407252.77908.72

Examination Committee of Criteria for 'Obesit Disease' in Japan. Japan Society for Study of Obesity (2002): New criteria for 'obesity disease'in Japan. Circulation Journal, 66(11): 987-992. DOI: $\underline{10.1253 / \text { circj.66.987 }}$

Fredriks, A.M., van Buuren, S., Fekkes, M., Verloove-Vanhorick, S.P., Wit, J.M. (2005): Are age references for waist circumference, hip circumference and waist-hip ratio in Dutch children useful in clinical practice? European Journal of Pediatrics, 164(4): 216-222. DOI: 10.1007/s00431-004-1586-7

Fujita, Y., Kouda, K., Nakamura, H., Iki, M. (2011): Cut-off values of body mass index, waist circumference, and waist-to-height ratio to identify excess abdominal fat. Journal of Epidemiology, 21: 191-196. DOI: 10.2188/jea.JE20100116

Garg, A. (2011): Lipodystrophies: genetic and acquired body fat disorders. Journal of Clinical Endocrinology \& Metabolism, 96(11): 3313-3325. DOI: 10.1210/jc.2011-1159

Hsieh, S.D., Yoshinaga, H. (1995): Abdominal fat distribution and coronary heart disease risk factors in men-waist/height ratio as a simple and useful predictor. International Journal of Obesity and Related Metabolic Disorders, 19(8): 585-589.

Jensen, M.D. (2008): Role of body fat distribution and the metabolic complications of obesity. Journal of Clinical Endocrinology \& Metabolism, 93(11): s57-s63. DOI: 10.1210/jc.2008$\underline{1585}$ 
Jeukendrup, A., Gleeson, M. (2010): Sport nutrition: an introduction to energy production and performance (2nd Edition). Human Kinetics, Champaign, IL, USA.

Kim, S.M., Kim, S.S., Yoon, S.J., Shim, K.W., Choi, H.J., Kim, K.M., Lee, D.J. (1998): What is the best simple anthropometric indexes of abdominal visceral fat in obese patients? Korean Journal of Obesity, 7: 157-168.

Lohman, T.G., Going, S.B. (2006): Body composition assessment for development of an international growth standard for preadolescent and adolescent children. Food and Nutrition Bulletin, 27: S314-S325.

Lobman, T.G., Houtkooper, L., Going, S.B. (1997): Body fat measurement goes high-tech: Not all are created equal. ACSM's Health \& Fitness Journal, 1(1): 30-35.

Ma, G.S., Li, Y.P., Wu, Y.F., Zhai, F.Y., Cui, Z.H., Hu, X.Q., Luan, D.C., Hu, Y.H., Yang, X.G. (2005): The prevalence of body overweight and obesity and its changes among Chinese people during 1992 to 2002. Zhonghua Yu Fang Yi Xue Za Zhi, 39: 311-315.

Magalhaes, E., Sant'Ana, L., Priore, S.E., Franceschini, S. (2014) Waist circumference, waist/height ratio, and neck circumference as parameters of central obesity assessment in children. Revista Paulista de Pediatria, 32(3): 273-281. DOI: 10.1590/0103-0582201432320

Okorodudu, D.O., Jumean, M.F., Montori, V.M., Romero-Corral, A., Somers, V.K., Erwin, P.J., Lopez-Jimenez, F. (2010): Diagnostic performance of body mass index to identify obesity as defined by body adiposity: a systematic review and meta-analysis. International Journal of Obesity, 34(5): 791-795. DOI: 10.1038/ijo.2010.5

Phillips, C.M., Tierney, A.C., Perez-Martinez, P., Defoort, C., Blaak, E.E., Gjelstad, I.M., Hall, W. (2013) Obesity and body fat classification in the metabolic syndrome: impact on cardiometabolic risk metabotype. Obesity, 21(1): 154-161. DOI: $10.1002 / 0 b y .20263$

Reilly, J.J. (2005): Descriptive epidemiology and health consequences of childhood obesity. Best Practice \& Research Clinical Endocrinology \& Metabolism, 19(3): 327-341. DOI: 10.1016/j.beem.2005.04.002

Shah, N.R., Braverman, E.R. (2012): Measuring adiposity in patients: the utility of body mass index (BMI), percent body fat, and leptin. PloS one, 7(4): e33308. DOI: 10.1371/journal.pone.0033308

Shen, W., Punyanitya, M., Silva, A.M., Chen, J., Gallagher, D., Sardinha, L.B., Allison, D.B., Heymsfield, S.B. (2009): Sexual dimorphism of adipose tissue distribution across the lifespan: a cross-sectional whole-body magnetic resonance imaging study. Nutrition \& Metabolism, 6(1): 17. DOI: $10.1186 / 1743-7075-6-17$

Siri, W.E. (1956): Body composition from fluid spaces and density. MS UCRL 3349. Donner Laboratory, University of California, Berkeley, CA, USA.

Smith, S.R., Lovejoy, J.C., Greenway, F., Ryan, D., de la Bretonne, J., Volafova, J., Bray, G.A. (2001): Contributions of total body fat, abdominal subcutaneous adipose tissue compartments, and visceral adipose tissue to the metabolic complications of obesity. Metabolism, 50(4): 425-435. DOI: 10.1053/meta.2001.21693

Taylor, R., Jones, I., Williams, S., Goulding, A. (2000): Evaluation of waist circumference, waistto-hip ratio, and the conicity index as screening tools for high trunk fat mass, as measured by dual-energy X-ray absorptiometry. American Journal of Clinical Nutrition, 72(2): 490-495.

Weiner, J.S., Lourie, J.A. (1969): Human Biology, A Guide to Field Methods.

Wells, J.C. (2007): Sexual dimorphism of body composition. Best Practice \& Research Clinical Endocrinology \& Metabolism, 21(3): 415-430. DOI: 10.1016/j.beem.2007.04.007

Weng, X., Liu, Y., Ma, J., Wang, W., Yang, G., Caballero, B. (2006): Use of body mass index to identify obesity-related metabolic disorders in the Chinese population. European Journal of Clinical Nutrition, 60: 931-937. DOI: 10.1038/sj.ejcn.1602396

World Health Organisation (1995): Physical Status: The use and interpreation of anthropometry. Technical Report Series 854. WHO, Geneva.

World Health Organization (2000): Obesity: preventing and managing the global epidemic. No. 894. World Health Organization. WHO, Geneva. 
World Health Organization (2011): Waist circumference and waist-hip ratio. Report of a WHO expert consultation. WHO, Geneva.

Zhou, B. (2002): Predictive values of body mass index and waist circumference to risk factors of related diseases in Chinese adult population. Zhonghua Liu Xing Bing Xue Za Zhi, 23: 5-10.

Zsákai, A., Jakab, K., Karkus, Z., Tóth, K., Kern, B., Vitályos, Á.G., Lichthammer, A., Balázsi, Sz., Gábor, Zs. (2007): New Hungarian national cut-off points of BMI for screening childhood underweight, overweight and obesity. Anthropologiai Közlemények, 48: 21-30.

Levelezési cím:

Zsákai Annamária

Mailing address:

Embertani Tanszék

Eötvös Loránd Tudományegyetem

Pázmány P. s. 1/c.

H-1117 Budapest

Hungary

zsakaia@elte.hu 